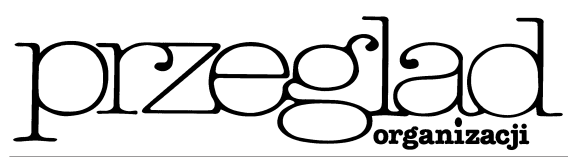

\title{
Koncepcje konkurencyjności przedsiębiorstwa
}

https://doi.org/10.33141/po.2005.09.01

Zdzisław Pierścionek
Przegląd Organizacji, Nr 9 (788), 2005, ss. 7-9 www.przegladorganizacji.pl Towarzystwo Naukowe Organizacji i Kierownictwa (TNOiK)
Koncepcja konkurencyjności przedsiębiorstwa oznacza generalny sposób radzenia sobie z konkurencją określający wiodące mechanizmy i narzędzia konkurowania w krótkim oraz długim okresie. Określona koncepcja konkurencyjności przedsiębiorstwa wynika z założeń co do otoczenia rynkowego oraz konkurencyjnego danego przedsiębiorstwa oraz założeń co do wewnętrznych i zewnętrznych źródeł konkurencyjności przedsiębiorstwa. Przyjęta koncepcja konkurencyjności przedsiębiorstwa stanowi podstawę budowy strategii konkurencji przedsiębiorstwa krótkookresowej (zestaw instrumentów konkurowania na ryn$\mathrm{ku}$ ) oraz długookresowej (kształtowanie rozwoju konkurencyjnych zasobów i umiejętności oraz relacji z konkurentami).

Podstawowe elementy składające się na koncepcję konkurencyjności przedsiębiorstwa to: • określone zestawy rynkowych instrumentów konkurowania, - określone źródła wewnętrzne i zewnętrzne rynkowej przewagi konkurencyjnej, - określone sposoby i struktury kształtowania konkurencyjnych zasobów i umiejętności, • określone sposoby usytuowania przedsiębiorstwa wobec konkurentów (konfrontacja, alianse, unikanie konkurencji, ignorowanie konkurencji) ${ }^{1}$. Na przykład koncepcja konkurencyjności przedsiębiorstwa określana jako przywództwo jakościowe oznacza, że podstawowym narzędziem konkurowania na rynku jest przewaga jakościowa, a źródłem tej przewagi są kompleksowe systemy sterowania jakością ciągle udoskonalane w procesie zbiorowego uczenia się wraz z wybranymi aliantami.

Składniki tworzące koncepcję konkurowania są ściśle wzajemnie powiązane, tak więc ich określenie odbywa się w złożonym procesie wzajemnych oddziaływań prostych i zwrotnych. Wśród różnych koncepcji konkurencyjności przedsiębiorstwa można wyróżnić takie, których punktem wyjścia są rynkowe czynniki konkurencyjności (marketingowa koncepcja konkurencyjności), działania przeciw konkurentom (na podstawie wiedzy o ich możliwościach, celach oraz strategiach), źródła przewagi konkurencyjnej przedsiębiorstwa (podejście zasobowe) oraz typ usytuowania przedsiębiorstwa wobec konkurencji. Można tu też mówić o podejściu zintegrowanym, a więc kojarzącym działania w stosunku do odbiorców, konkurentów (oraz innych składników otoczenia), określającym czynniki i mechanizmy konkurowania w jednym zintegrowanym, iteracyjnym procesie ze sprzężeniami zwrotnymi.

Teoria i praktyka dopracowała się wielu różnorodnych koncepcji konkurencyjności przedsiębiorstwa. Różnią się one, obok już wymienionych cech, stopniem koncentracji uwagi na wyżej wymienionych składnikach, głębokością i uniwersalnością ujęcia źródeł przewagi konkurencyjnej oraz stopniem kompleksowości ujęcia problemu konkurencyjności, w tym w aspekcie horyzontu czasowego.

Tradycyjne koncepcje konkurencyjności przedsiębiorstwa koncentrowały się na podstawowych rynkowych czynnikach konkurencyjności (koszty, jakość, marketing, pozycja na rynku) oraz bezpośrednich ich źródłach. Najważniejsze z nich są następujące:

- koncepcja konkurencyjności kosztowej bazująca na efektach wielkiej skali produkcji, specjalizacji, standaryzacji oraz efektach doświadczenia,

- przywództwo jakościowe oraz systemy sterowania jakością,

- konkurowanie oparte na sile rynkowej przedsiębiorstwa (pozycja lidera oraz dominanta na rynku),

- marketingowa koncepcja konkurencyjności,

- przywództwo kosztowe oraz dyferencjacja.

Tradycyjne koncepcje konkurencyjności zakładały wiodącą rolę w czynnikach konkurencyjności na rynku kosztów, następnie jakości, a dalej różnicowania ofert oraz intensywnej promocji. Jako źródła przewagi konkurencyjnej traktowane są bezpośrednie źródła, jak: specjalizacja, doświadczenie, systemy sterowania jakością, strategie marketingowe. Tradycyjne koncepcje zakładały istnienie konkurencji w formie oligopolu oraz konkurencji monopolistycznej. Zakładano, że przedsiębiorstwa nie są skłonne do współpracy, a więc przyjmują postawę konfrontacyjną.

Nowe koncepcje konkurencyjności przedsiębiorstwa związane są z innowacjami, przedsiębiorczością oraz aliansami. Innowacje oraz przedsiębiorczość stanowią podstawowy wyróżnik nowych koncepcji konkurencyjności przedsiębiorstwa. Między innymi M. Porter twierdzi, że istnieją dwa zasadniczo różniące się podejścia do konkurencyjności, tj. ${ }^{2}$ :

- konkurowanie przez restrukturyzację,

- przedsiębiorcza koncepcja konkurencyjności.

Konkurowanie przez restrukturyzację (oraz rozwiniętą jej formę, tj. reengineering) polega na konkurencji kosztowej przez ciągła restrukturyzację rozumianą głównie jako redukcję zatrudnienia, produktów oraz rynków. Koncepcja przedsiębiorcza zakłada, że konkurencyjność (trwałą) można osiąnąć tylko przez ciągłe opracowywanie i wdrażanie innowacji, kreowanie nowego klienta i nowych rynków, poszukiwanie nowych okazji, wchodzenie na nowe rynki i dziedziny. Wymienione tradycyjne koncepcje nie maja charakteru przedsiębiorczego, mają zaś wiele cech podejścia restrukturyzacyjnego. 
Nowe koncepcje konkurencyjności przedsiębiorstwa związane są z nowymi warunkami otoczenia konkurencyjnego. Konkurencja z lokalnej oraz krajowej przekształciła się w wielu sektorach w międzynarodową oraz globalną. Wzrosło tempo zmian otoczenia rynkowego, technologicznego oraz konkurencyjnego. W tej sytuacji przedsiębiorstwa muszą tworzyć „międzynarodowe” koncepcje konkurencyjności, a więc zarówno od strony instrumentów rynkowych, jak i źródeł konkurencyjności - dostosowane do nowej sytuacji. Jedną z podstawowych cech nowych koncepcji konkurencyjności jest wysoka skłonność przedsiębiorstwa do współpracy. Tzw. relacyjna teoria konkurencji zakłada, że przedsiębiorstwa w swoich zachowaniach dążą do ograniczenia konkurencji, porozumień i aliansów ${ }^{3)}$. Inne założenia co do charakteru konkurencji oraz rynków przyjmuje tzw. teoria hiperkonkurencji. Wysokie tempo zmian otoczenia rynkowego, technologicznego oraz konkurencyjnego powoduje pojawienie się konkurencji o nowych jakościowo cechach, które wymagają nowych metod ich analizy oraz nowych strategii. Tradycyjny model konkurencji zakłada stabilność przewagi konkurencyjnej przedsiębiorstwa. W warunkach bardzo szybkich zmian tradycyjne strategie nie są skuteczne (przywództwo kosztowe, dyferencjacja). Nowa strategia konkurencji ma polegać na ataku na konkurentów, dynamizacji ryn$\mathrm{ku}$, wyjściu z rynku w odpowiednim momencie oraz przeniesieniu się na nowy rynek, który zapewni dalsze sukcesy. Przedsiębiorstwo działa w warunkach sekwencji krótkookresowych przewag konkurencyjnych, nie zaś stabilnej długookresowej przewagi. To co decyduje o sukcesie przedsiębiorstwa, to umiejętności zachowania w ramach tych czterech działań, umiejętności efektywnego kreowania sekwencji krótkookresowych przewag konkurencyjnych. Trwała przewaga konkurencyjna wynika z umiejętności kreowania krótkotrwałych przewag konkurencyjnych ${ }^{4)}$.

W latach 80. i 90. ub. wieku rozwijają się zasobowe koncepcje konkurencyjności przedsiębiorstwa, które można określić jako kompleksowe, identyfikujące bazowe źródła przewagi konkurencyjnej przedsiębiorstwa oraz zasady ich rozwijania w długim okresie. Najważniejsze z nich są następujące:

- konkurowanie na bazie czasu (time-based competition),

- konkurowanie na podstawie zdolności firmy (capabilities-based competition),

- koncepcja zakładająca podstawową rolę w konkurencyjności rozwijania i tworzenia kluczowych kompetencji (core competences of the corporation),

- koncepcja konkurencyjności zakładająca wiodąca rolę identyfikacji wyróżniających firmę zdolności oraz dostosowania do nich domeny działania (distinctive capabilities).

Koncepcje zasobowe, mające charakter przedsiębiorczy, określają bazowe źródła przewagi konkurencyjnej przedsiębiorstwa. Można uznać, że tradycyjne koncepcje konkurencyjności przedsiębiorstwa określały bezpośrednie źródła przewagi konkurencyjnej przedsiębiorstwa, np. kosztowej, czy jakościowej, w postaci np. skali produkcji, technologii, doświadczenia, czy zarządzania jakością. Nowe zasobowe koncepcje starają się wyjaśnić, co jest przyczyną konkurencyj- nych zdolności innowacyjnych przedsiębiorstwa, wyższej jakości produkcji, niższych kosztów, czy konkurencyjnej strategii marketingowej. Te źródła są określane w kategoriach zbioru wiedzy i umiejętności oraz zintegrowanego zbioru technologii i umiejętności ich wykorzystania.

Konkurencyjność przedsiębiorstwa należy rozpatrywać w łańcuchu powiązań przyczynowo-skutkowych, w którym staramy się określić poszczególne ogniwa będące coraz głębszymi przyczynami (źródłami) przewagi. Konkurencyjna na przykład jakość, cena oraz promocja danego przedsiębiorstwa są efektem posiadania konkurencyjnej technologii, konkurencyjnej organizacji zaopatrzenia oraz konkurencyjnej strategii marketingowej, strategii konkurencji oraz rozwoju. Te konkurencyjne warunki osiągane są w przedsiębiorstwie, które posiada konkurencyjną formę organizacyjną oraz konkurencyjny system zarządzania, $\mathrm{w}$ tym system informacji. Stawiając następne z kolei pytania o przyczynę przewagi w zarządzaniu dochodzimy do wiedzy oraz umiejętności jej wykorzystania. Wiedzy dotyczącej zarówno procesów regulacyjnych w przedsiębiorstwie, jak i realnych. Wiedza i umiejętności o specjalnych cechach tworzą kluczowe kompetencje (czy wyróżniające firmę zdolności), które ukierunkowują rozwój wiedzy i umiejętności w przedsiębiorstwie. Wiedza i umiejętności, w tym te tworzace kluczowe kompetencje, tworzone są w przedsiębiorstwie w procesie wewnętrznego, tj. organizacyjnego uczenia się, jak i pod wpływem otoczenia. Schemat zależności przyczynowo-skutkowych tworzenia konkurencyjności przedsiębiorstwa przedstawiono na rysunku.

W'śód koncepcji konkurencyjności można wyróżnić takie, które koncentrują się na czynnikach realnych (sfera realna) oraz regulacyjnych (sfera regulacji) konkurencyjności. Te pierwsze zajmują się wpływem technologii, specjalizacji, dywersyfikacji, skali produkcji, doświadczenia, zasobów surowcowych, infrastruktury, siły roboczej oraz lokalizacji na konkurencyjność przedsiębiorstwa. Te drugie w centrum uwagi stawiaja systemy informacyjne, metody i procedury podejmowania decyzji, zasoby wiedzy i umiejętności jej wykorzystania, metody i procedury uczenia się organizacji, formy organizacyjne przedsiębiorstwa oraz struktury zarządzania.

Tradycyjne koncepcje konkurencyjności przedsiębiorstwa koncentrują się na realnych czynnikach i mechanizmach konkurencyjności, natomiast nowe na czynnikach i mechanizmach sfery regulacji. Należy tu wymienić następujące, uważane za nowe, koncepcje konkurencyjności przedsiębiorstwa:

- informacja oraz systemy informatyczne - jako źródło przewagi konkurencyjnej,

- wirtualne formy organizacyjne oraz sieci przedsiębiorstw,

- organizacje uczace się oraz oparte na wiedzy.

Koncepcje te należą do typu przedsiębiorczego. Można je uznać, wraz z nowymi koncepcjami zasobowymi, jako określone warianty mechanizmów tworzenia i rozwoju zdolności innowacyjnych przedsiębiorstwa.

Umiędzynarodowienie oraz globalizacja przedsiębiorstw są powszechnym kierunkiem rozwoju współ- 


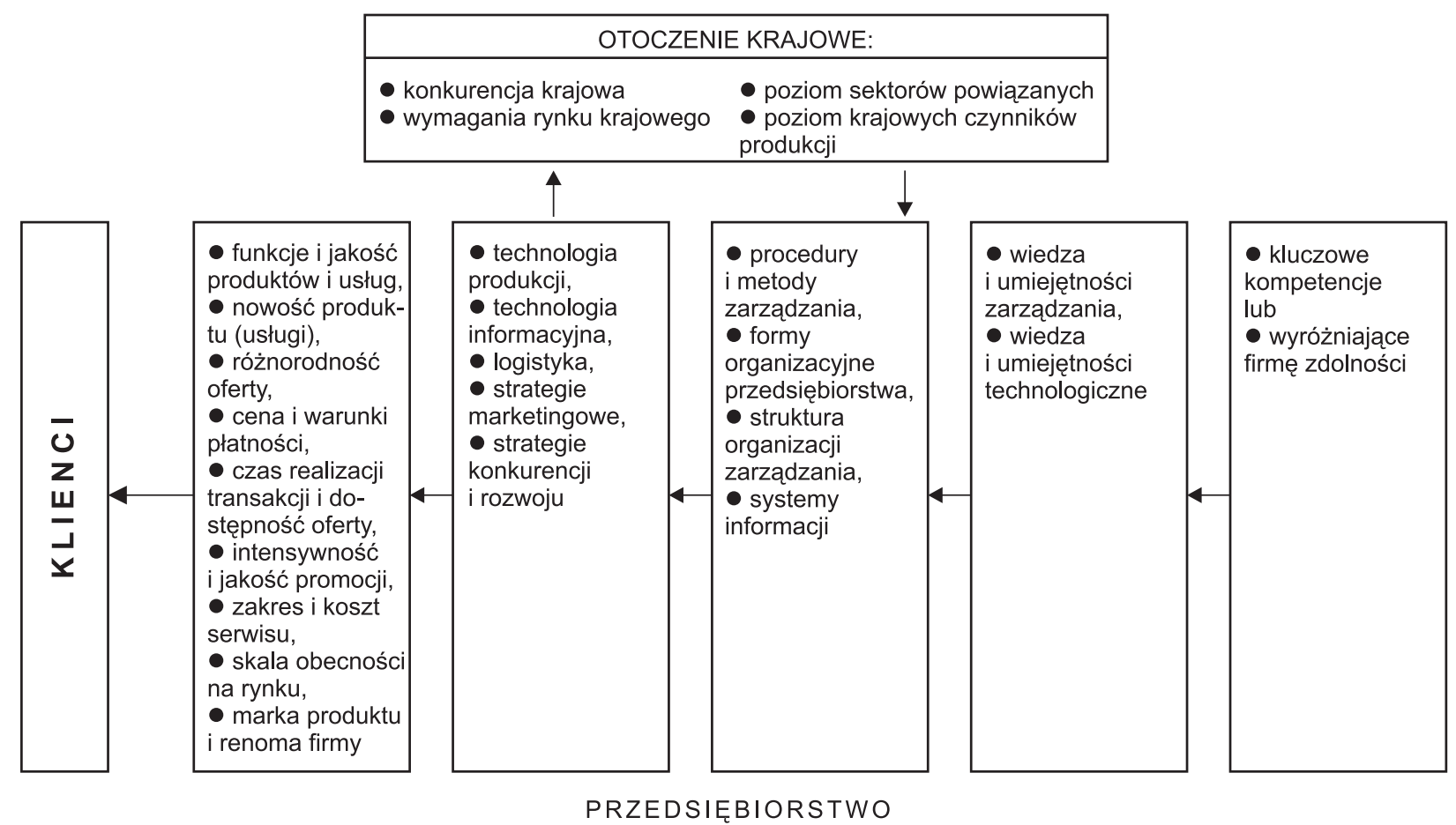

Rys. Łańcuch przyczynowo-skutkowy tworzenia konkurencyjności przedsiębiorstwa

czesnych przedsiębiorstw. Stwarzają one ogromne możliwości wzrostu konkurencyjności przedsiębiorstwa. Te możliwości różnie ujmują różne teorie źródeł przewagi konkurencyjnej przedsiębiorstw międzynarodowych (korporacji ponadnarodowych). Wśród wielu wariantów koncepcji konkurencyjności przedsiębiorstwa w aspekcie międzynarodowych rynków czynników produkcji oraz międzynarodowych struktur organizacyjnych przedsiębiorstwa można wymienić następujące:

- koncepcja konkurencyjności bazująca na korzyściach komparatywnych,

- koncepcja konkurencyjności bazująca na strategicznych źródłach przewagi konkurencyjnej w układzie międzynarodowym,

- koncepcja integrująca czynniki komparatywne oraz strategiczne (strategia międzynarodowa, multinarodowa, globalna oraz transnarodowa),

- paradygmat internalizacja - lokalizacja - zasoby własne.

„Międzynarodowe” koncepcje konkurencyjności przedsiębiorstwa ujmują głównie zewnętrzne, w stosunku do zasobów przedsiębiorstwa, źródła przewagi konkurencyjnej. Te źródła można podzielić na komparatywne oraz strategiczne. Źródłem przewagi konkurencyjnej jest odpowiednia lokalizacja różnych działalności w krajach o różnych zasobach, umiejętnościach i cenach siły roboczej, poziomie technologii, infrastruktury, zasobów surowcowych. Źródłem przewagi konkurencyjnej jest, po drugie, zastosowanie odpowiednich struktur oraz strategii, w tym koncentracji, specjalizacji, koordynacji oraz internalizacji ${ }^{5}$.

Tradycyjne koncepcje konkurencyjności przedsiębiorstwa, a także nowe koncepcje zasobowe nie odnoszą się do źródeł konkurencyjności przedsiębiorstwa tkwiących w czynnikach produkcji różnych krajów oraz $\mathrm{w}$ międzynarodowych strukturach organizacyjnych przedsiębiorstw. Umiędzynarodowienie i globalizacja oznaczają nowe źródła przewagi konkurencyjnej przedsiębiorstwa, niedostępne dla przedsiębiorstw lokalnych oraz krajowych. W procesie przekształcenia przedsiębiorstwa krajowego w międzynarodowe, a dalej w globalne, następuje proces umiędzynarodowienia jego strategii konkurencji oraz źródeł przewagi konkurencyjnej. Polega on, po pierwsze, na wykorzystaniu efektów komparatywnych oraz strategicznych, jakie stwarza lokalizacja różnych działalności przedsiębiorstwa w różnych krajach. Po drugie, umiędzynarodowienie przedsiębiorstwa stwarza nowe możliwości rozwoju i tworzenia kluczowych kompetencji przedsiębiorstwa. Tak więc istnieje potrzeba zintegrowania zasobowych teorii konkurencyjności, na przykład kluczowych kompetencji, oraz „międzynarodowych" teorii konkurencyjności.

Przedstawionych koncepcji konkurencyjności przedsiębiorstwa nie należy traktować jako alternatyw. Reprezentują one różne aspekty koncepcji konkurencyjności. Tak więc w praktyce wybrane koncepcje sa integrowane w pewnych wybranych ich fragmentach. Najczęściej próbuje się integrować koncepcje zasobowe oraz regulacyjne.

prof. zw. dr hab. Zdzistaw Pierścionek Szkoła Główna Handlowa

\section{PRZYPISY}

1) Por. Z. PIERŚCIONEK i in., Czynniki sukcesu polskich przedsiębiorstw na rynku UE, - Ministerstwo Nauki i Informatyzacji 2005.

2) M. PORTER, Porter o konkurencji, PWE, Warszawa 2001.

3) Por. np. STRATEGOR, Zarzqdzanie firma, PWE, Warszawa 1999 , s. 254.

4) R.A. D'AVENI, Hypercompetitive Rivalries, The Free Press, New York 1995, s. 220.

5) Internalizacja oznacza wewnętrzne przepływy materialne i niematerialne między zagranicznymi filiami i oddziałami korporacji ponadnarodowych. 